\title{
Metastatic ovarian malignant melanoma with no obvious primary
}

\author{
Primer odağı belli olmayan metastatik Over melanomu \\ Ateş Karateke', Niyazi Tuğ $\breve{1}^{1}$ Davut Şahin ${ }^{2}$ \\ 'Department of Gynecologic Oncology, Zeynep Kamil Hospital, Istanbul, Turkey \\ ${ }^{2}$ Department of Pathology, Zeynep Kamil Hospital, Istanbul, Turkey
}

\section{Abstract}

The differential diagnosis of metastatic ovarian malignant melanoma from primary ovarian tumors is a significant challenge, particularly if there is no obvious primary site. A 39 -year-old patient with bilateral ovarian malignant melanoma presented as stage IV primary ovarian tumor, with metastases in the omentum and spleen. She underwent a total abdominal hysterectomy and bilateral salpingo-oopherectomy with infracolic omentectomy and splenectomy. The diagnosis on examination of frozen sections was inconclusive. The final diagnosis was made by immunohistochemistry. The sections showed positive staining with HMB-45, vimentin, S-100, and no staining for cytoceratin, inhibin, calretinin and caldesmon. After the operation, the MRI at the $14^{\text {th }}$ postoperative day revealed metastatic lesions in the vertebrae, sacrum, bilateral humerus and femur and in the cerebral cortex, together with edema and hemorrhagic foci. The patient stayed in the intensive care unit for 12 weeks until her death due to cardio-respiratory arrest. This case highlights the clinical fact that metastatic malignant melanoma may mimic primary ovarian tumor with an occult or regressed primary. Both the standard pre-operative imaging modalities (such as CT, MRI) and the histo-pathologic examination of the frozen sections may be inconclusive in the differentiation of ovarian melanoma from epithelial ovarian malignancies. The final diagnosis could be established by immunohistochemistry. Intra-abdominal debulking surgery would not prolong the survival of metastatic ovarian melanoma because of the occult or rapid metastasis to the extra abdominal sites of the tumor. (J Turkish-German Gynecol Assoc 2011; 12: 181-2) Key words: Melanoma, ovary, metastatic melanoma, amelanotic melanoma

Received: 26 July, 2010

Accepted: 5 September, 2010

\section{Özet}

Metastatik overyan malign melanomun primer over tümörlerinden ayırt edilmesi, özellikle primer odağın belli olmadığı olgularda oldukça zordur. 39 yaşında bilateral overyan malign melanomu olan hasta, dalak ve omentumda metastazları mevcut evre IV primer over tümörü olarak prezente olmuştur. Hastaya total abdominal histerektomi, bilateral salpingo-ooferektomi, infrakolik omentektomi ve splenektomi yapılmıştır. Frozen seksiyonda tanı şüpheli olup kesin tanı immünohistokimyasal boyama sonrası konulabilmiştir. Kesitlerde HMB-45, vimentin ve S-100 müsbet, sitokeratin, inhibin, kalretinin ve kaldezmon menfi boyanma göstermiştir. Post-operatif 14 . günde yapılan MRI incelemesinde vertebra, sakrum, bilateral humerus ve femur ve serebral korteksde metastatik lezyonlar, ödem ve hemorajik lezyonlar saptanmıştır. Hasta 12 hafta boyunca, burada kalp-solunum yetmezliği sonucu hayatını kaybedinceye kadar yoğunbakım ünitesinde kalmıştır. $\mathrm{Bu}$ olgu, primer odağı gizli yada regrese olmuş metastatik malign melanomun primer over tümörlerini taklit edebileceğini vurgulamaktadır. Hem tomografi ve MRI gibi standart pre-operatif görüntüleme yöntemleri, hemde frozen seksiyon incelemesi overyan melanomun epitelyal over malignensilerinden ayırt edilmesinde yetersiz kalmaktadırlar. Kesin tanı immünohistokimyasal incelemeyle konulabilir. İntra-abdominal debulking cerrahi metastatik ovaryan melanomda, tümörün ekstra-abdominal bölgelere gizli veya erken metastaz yapması sebebiyle yaşam süresini uzatmamaktadır.

(J Turkish-German Gynecol Assoc 2011; 12: 181-2)

Anahtar kelimeler: Melanom, over, metastatik melanom, amelanotik melanom

Geliş Tarihi: 26 Temmuz $2010 \quad$ Kabul Tarihi: 05 Eylül 2010

\section{Introduction}

Melanoma in the ovary is a rare condition often found at autopsy as a part of extensive multi-systemic spread of the disease. Primary ovarian melanomas usually arise from a benign cystic teratoma. In the majority of metastatic ovarian melanomas, the primary lesion is in the skin and may present clinically even after long periods of remission. Presentation as solitary organ tumors has also been reported. Diagnosis of the metastatic ovarian melanomas is difficult, especially if the primary lesion is not prominent (1-3). The reported case is a bilateral amelanotic metastatic ovarian melanoma presenting as a primary ovarian tumor with no obvious primary site.

\section{Case Report}

A 39 year old multiparous female with a complaint of abdominal mass was referred to our clinic. Her personal history for cancer was unremarkable. She had bilateral ovarian solid masses completely occupying the recto-uterine space and ascites. MRI and CT revealed enlarged pelvic lymph nodes on the right side and metastatic lesions in the omentum and spleen. No lesion was observed in the thorax CT. Among tumor markers, CA125 was $404 \mathrm{IU} / \mathrm{L}$ while others were normal. Pre-operative diagnosis was stage IV ovarian cancer and optimal debulking surgery was performed.

Gross examination of the excised material revealed soft, hemorrhagic, necrotic white-yellow tumor tissue. The spleen

Address for Correspondence: Uzm. Dr. Niyazi Tuğ, Burhanettin Üstünel Cad., No: 20, Üsküdar 34668 İstanbul, Turkey

Phone: +90505 5143541 e.mail: niyazitug@hotmail.com

(C) Copyright 2011 by the Turkish-German Gynecological Education and Research Foundation - Available on-line at www.jtgga.org doi:10.5152/jtgga.2011.41 

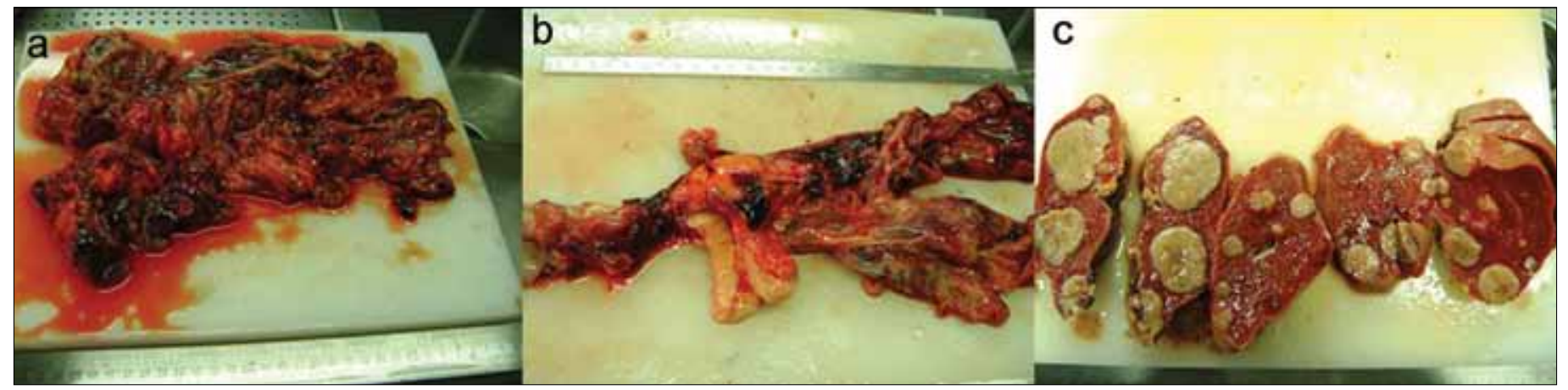

Figure 1. Macroscopic view of the resected specimens: a) Hemorrhagic, necrotic gross appearance of the tumor resected from the abdomen b) hysterectomy material c) spleen

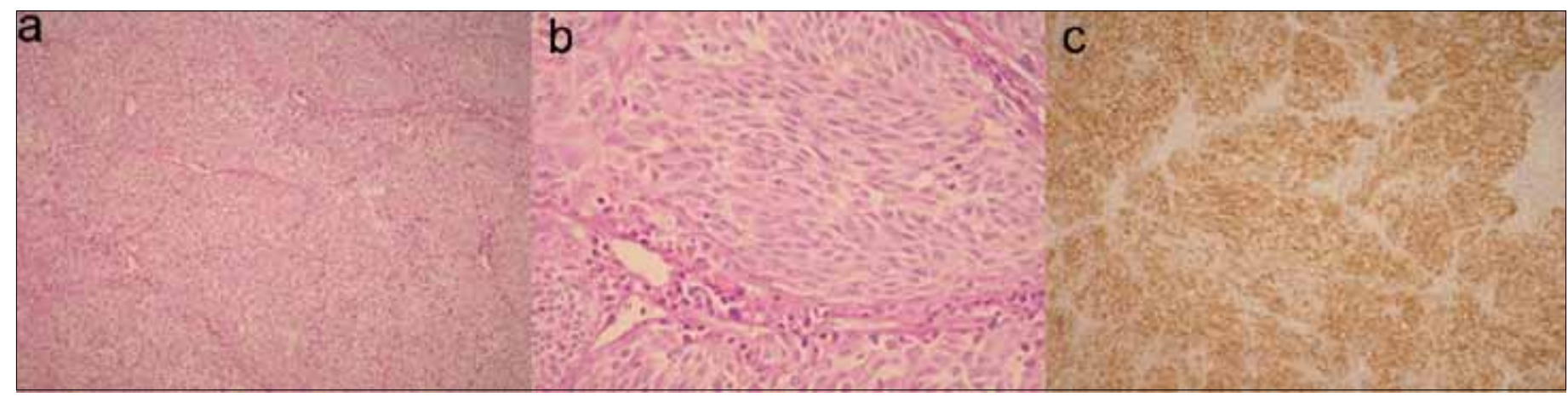

Figure 2. Microscopic examination of the tumor a) nested architecture of the tumor (HE. $x$ 100) b) Spindle shape tumor cells with prominent nucleolus (HE. x 400) c) Immunoreactivity for HMB-45 (x 100)

contained white metastatic lesions (Figure 1a-c). On frozen sections, microscopy revealed a predominantly diffuse growth pattern with focal nested architecture, coagulation necrosis and gland-like structures. The tumor was composed of large epithelioid cells with eosinophilic cytoplasm and spindleshaped cells, with prominent nucleoli. The diagnosis according to the examination of frozen sections was malignant tumor of unknown origin.

The final histo-pathologic diagnosis was metastatic malignant melanoma based on the observation of positivity for S-100, HMB45 and Masson-Fontana and negativity for cytoceratin, inhibin, calretinin and caldesmon and the absence of a cystic teratoma. No peri-operative surgical complication occured but a pleural effusion developed on the $2^{\text {nd }}$ postoperative day. MRI on the $14^{\text {th }}$ postoperative day revealed many metastatic lesions in the vertebrae, sacrum, humerus, femur, and cerebral cortex. The patient stayed in intensive care unit for 12 weeks until her death.

\section{Discussion}

Preoperative assessment of ovarian melanoma should involve sensitive screening modalities to assess metastases because ultrasonography and tomography usually fail to characterize these lesions. MRI may be helpful if there is a considerable amount of melanin deposited in the lesions but the majority of ovarian melanomas are amelanotic (4). Positron Emission Tomography scans have been shown to be sensitive and specific in detecting metastases of the melanomas (5).

This case highlights the clinical fact that metastatic malignant melanoma may mimic a primary ovarian tumor with an occult or regressed primary. A regressed cutaneous melanoma or a primary site of mucosal surfaces might be an explanation for a possibly undetected primary origin. Both the standard pre-operative imaging modalities (such as CT, MRI) and the histo-pathologic examination of the frozen sections may be inconclusive in the diagnosis of ovarian melanoma. The final diagnosis could be established by immunohistochemistry. Intra-abdominal debulking surgery would not prolong the survival of metastatic ovarian melanoma because of the occult or rapid metastasis to the extra abdominal sites of the tumor.

\section{Conflict of interest}

No conflict of interest was declared by the authors.

\section{References}

1. Ariel IM. Malignant melanoma of the female genital system: a report of 48 patients and review of the literature. J Surg Oncol 1981; 16: 371-83. [CrossRef]

2. Gupta D, Deavers M, Silva E, Malpica A. Malignant melanoma involving the ovary: a clinicopathologic and immunohistochemical study of 23 cases. Am J Surg Pathol 2004; 28: 771-80. [CrossRef]

3. Young RH, Scully RE. Malignant melanoma metastatic to the ovary: a clinicopathologic analysis of 20 cases. Am J Surg Pathol 1991; 15: 849-60. [CrossRef]

4. Moselhi M, Spencer J, Lane G. Malignant melanoma metastatic to the ovary: presentation and radiological characteristics. Gynecol Oncol 1998; 69: 165-8. [CrossRef]

5. Holder WD, White RL, Zuger JH, Easton EJ, Green FL. Effectiveness of positron emission tomography for the detection of melanoma metastases. Ann Surg 1998; 227: 764-71. [CrossRef] 